\title{
Chapter 7 \\ The Indigenous Voice in Majority Media. South Saami Representations in Norwegian Regional Press 1880-1990
}

\author{
Asbjørn Kolberg
}

\begin{abstract}
This chapter presents a study of how South Saami people and Saami affairs are represented in central Norwegian regional newspapers from around 1880 to 1990. Papers published in Steinkjer, the regional capital of Nord-Trøndelag County, constitute the bulk of the material. To what extent and how are Saami affairs represented in the newspapers? How do the papers represent South Saami identity? How and why do these representations change and to what extent and how are South Saami voices represented? The predominant topics are Reindeer herding, Saami politics, Education and language, History and culture. The period of my study coincides with the culmination and, from around 1970, the gradual elimination of the Norwegian assimilation policy practised on the Saami population. Social Darwinist or racial biological views are practically non-existent in my material, although quite common in the late nineteenth and early twentieth centuries topographical literature about the Saami. There are examples of stereotyping and othering, mostly before the 1960s, but in general, the regional newspapers in my study take a respectful interest in Saami affairs, although Saami affairs do not make up a substantial part of the newspaper content until the 1970s.
\end{abstract}

Iktedimmieh Daate tjaalege aktem goerehtimmiem åehpiedahta guktie lea åarjelsaemiej jïh saemien aamhtesi bïjre tjaalasovveme vihkeles nöörjen regijonaale plaerine jaepiej 1880-1990. Tjaalegh mah leah bæjhkoehtamme plaerine Stientjesne, dajven åejviestaare Noerhte-Trööndelagen fylhkesne, leah åejviebielie materijaaleste. Mennie mieresne jïh guktie saemien aamhtesi bïjre tjaaleme plaerine? Guktie plaerieh dam åarjelsaemien identiteetem åehpiedehtieh? Guktie jïh man åvteste daah åehpiedehtemh jarkesieh, jïh mennie mieresne jïh guktie åarjelsaemien gielh våajnoes dorjesovveme? Doh aamhtesh mej bïjre jeenjemes tjaelieh leah båatsoe, saemien politihke, ööhpehtimmie jïh gïele, histovrije jïh kultuvre. Manne lim studente don baelien gosse ïedtje lij læsseneminie, jïh ovrehte 1970 raejeste dihte

This chapter is an elaboration of an article published in the Norwegian journal Heimen (Kolberg in Heimen, 2018).

\footnotetext{
A. Kolberg $(\varangle)$

The Faculty of Education and Arts, Nord University, Levanger, Norway

e-mail: asbjorn.kolberg@nord.no 
ånnetji ånnetji nåhkehtimmie nöörjen assimilasjovnepolitihkeste lissiehtamme dejtie saemien årroejidie. Sosijaaledarwinisteles jallh biologeles vuajnoeh naelien bïre eah mov materijaalesne gååvnesh gænnah, men lea naa sïejhme topografeles lidteratuvresne saemiej bïjre 1800-låhkoen raejeste jïh aareh 20. tjuetiejaepien raajan. Vuesiehtimmieh gååvnesieh stereotypijde jïh jeatjabidie, jeenjemes 1960-låhkoen åvtelen, men mov goerehtimmesne gujht regijovnaale plaerieh aktem eensi iedtjem utnieh saemien aamhtesidie, jalhts saemien aamhtesh eah leah akte stoerre bielie plaerien sisvegistie 1970-låhkoen.

\subsection{Introduction}

When the small market town of Levanger in central Norway celebrated its millennium in 2011, there was no mention of the Saami people in the official documents or the official events. Even the publication describing the traditional winter market fails to mention a single word about the Saami (Eliassen et al. 2007). This is quite odd as the Saami were significant participants in the market (documented by, e.g. Hammond 1787; Allingham 1807; Trapness 2002). In my view, this is a striking example of how time and again Saami presence has been obscured in regional and national history throughout the twentieth century, even till this day.

Levanger is one of the municipalities in the Innherred region of Trøndelag county. Trøndelag is in the southernmost part of Saepmie, the traditional Saami homeland. For the past century, Saami presence has not been very visible in the Innherred municipalities even though all have reindeer grazing districts. Growing up in Levanger in the 1960s, I frequently came across herds of reindeer on my skiing trips in the hills east of town. I knew that the Saami owned the reindeer, but I did not know who the reindeer herders were and where they lived. As a boy, I had the idea that the local Saami did not express their 'Saaminess' the way the Saami of the far north did. My idea of Saami culture was based on mass media representations of the Saami, e.g. in films like Same Jakki (1957) and Laila (1958); both set in Finnmark, in the very north. ${ }^{1}$

Was Saami presence generally as invisible in my county as I experienced it to be in my hometown? The answer is that the presence was indeed more significant in some municipalities, especially along the Swedish border, but my majority mindset was not calibrated to perceive this Saami presence. Even if I saw the reindeer and the reindeer fences, I did not realize the significance of Saami culture and history in my county. In this respect, I think I can speak for many of my generation.

It is interesting, then, that the first national congress of the Saami people took place in our regional capital, Trondheim, 100 years ago from 6 to 9 February 1917. The key participants in the meeting were all from the South Saami area, as were also most of the delegates. This means that though being relatively few in number,

\footnotetext{
${ }^{1}$ Even though Same Jakki was expressively made to counterbalance the exotic image of the Saami, there is still a subtext of "romantic primitivism" according to Christensen (2012, p. 14).
} 
the South Saami played a significant role in the early political manifestation of the Saami-in a context of assimilation policy, national restriction of reindeer herding and a Social Darwinist view of the Saami as an inferior people (Lundmark 2008; Fjellheim 2012; Jordheim 2015, 34-41; Salvesen 2017). The Trondheim newspapers and the national press covered the congress (Lien 2011). What about the small-town papers of the Innherred region? Did they cover the 1917 congress? Did they give any space at all to Saami affairs before and after the meeting? In fact, they did, but the scope and significance vary throughout the century.

In this chapter, I will seek to answer the following questions: To what extent and how are Saami people and Saami affairs represented in the regional newspapers of Innherred from the latter part of the nineteenth century until 1990? To what extent and how are the Saami voices represented? Furthermore, I will discuss how (South) Saami identity has been constituted, negotiated and represented in the various newspaper texts of my research. As a backdrop, I have also analysed texts that represent what I choose to call the Social Darwinist influenced discourse of racial biology around 1900; e.g. contemporary topographical literature presenting the Saami people (Helland 1899; Nielsen 1883, 1900, 1909; Nissen 1914). Thus, another question I ask is whether there is any echo of this racial biological discourse in the local/regional newspapers of my study.

\subsection{Material and Method}

The great bulk of my material comprises texts from the regional newspaper Tr $\phi$ nderAvisa (TA) and its predecessors published in Steinkjer and Levanger from the latter part of the nineteenth century to $1990 .^{2}$ Over the past decades, $T A$ has become the largest newspaper in Nord-Trøndelag County and is generally considered to serve as a mouthpiece for farming interests. ${ }^{3}$

The only Saami newspaper published in the South Saami region of Norway in the period, Waren Sardne (1910-13 and 1922-27) played an important role in the political manifestation of the Saami in the early twentieth century. The need for a Saami newspaper is mentioned in the agenda of the early Saami meetings referred to in my material, but only once have I registered that any of the majority papers refer

\footnotetext{
${ }^{2}$ Indherreds-Posten (1862-1924), Nordenfjeldsk Tidende (1874-1921), Indtrøndelagen (1900-1940), Indherred (1910-1919) which changed its name to Nord-Trøndelag in 1919. In 1922, it was merged with Nordenfjeldsk Tidende; named Nord-Trøndelag og Nordenfjeldsk Tidende. All the papers are predecessors of Nord-Trøndelag \& Inntrøndelagen, established in 1940, and which changed its name to Trønder-Avisa in 1952.

${ }^{3}$ Politically, all the papers have represented the Norwegian Liberal Party (Venstre) or offshoots of the liberal party. Thus from 1920, Nord-Trøndelag represented the agrarian Centre Party (Bondepartiet/Senterpartiet). Until 1996, TA had political editors for both Venstre and Senterpartiet.
} 
to Waren Sardne as a news source. ${ }^{4}$ This indicates how difficult it could be for Saami media to have a voice in society through their own channels.

I have registered the occurrence of Saami-related news items, articles, interviews and other texts in the newspapers and studied the texts from the perspective of critical text analysis and media history. My approach is a combination of quantitative and qualitative contents analysis. ${ }^{5}$ I have quantified the various texts according to genre and topics and analysed how the texts reflect opinion and attitudes, perspective and bias throughout the period studied. As my timespan is quite long, the material has given me the opportunity to observe changing trends in how the newspapers cover Saami affairs, not least in the light of the changing majority policy for the Saami in the period covered.

The text material is analysed in the light of contemporary social, cultural and political discourses and genre conventions. I have taken into consideration the development of Norwegian newspapers from the 1880s until the contemporary time to avoid the obvious pitfall of reading the old newspapers solely through the glasses of our own time. Genre conventions are not static. Nonetheless, the genres as we know them in present-day Norwegian newspapers seem to find their main characteristics by the end of the 1930s (Ottosen 2010, 153-173). In the next two sections, I will present previous research on Saami media representations and then account briefly for how I have categorized and systematized my material according to genres and topics.

\subsection{Previous Research}

There are a few studies on Saami media. Skogerb $\varnothing$ (2003) analyses the coverage of Saami affairs in national and regional news media during two given weeks in 1999. In her conclusion, she states that the Norwegian media tend to represent Saami affairs in a stereotypical or conflict-oriented way (Skogerbø 2003, 395). Ijäs (2012, 2015) has explored the coverage of news stories with a Saami focus in the northern Norwegian regional paper Nordlys (Troms $\varnothing$ ) and the national TV daily news broadcast Dagsrevyen (Norwegian Broadcasting Corporation) during the period 1970-2000. He shows how the Saami, from being almost invisible in Nordlys until the end of the 70 s, became significantly more visible before and after the so-called Alta conflict. ${ }^{6}$ After this event, the number of Saami news items dropped again. However, in the wake of the conflict, Nordlys took a greater interest in matters relating to Saami culture and society (Ijäs 2015, 91).

\footnotetext{
${ }^{4}$ In Inntrøndelagen 21/01/1927, there is a short news item about a young reindeer herder found frozen to death in the mountains. The source referred to is Waren Sardne.

${ }^{5}$ Although Krippendorff $(2004,16)$ disputes the distinction between quantitative and qualitative content analysis as all reading of texts is ultimately qualitative, I use the distinction to show how the occurrence of Saami-related texts changes throughout the period which I have studied.

${ }^{6}$ The political struggle against the building of the hydroelectric power plant in the Alta river in Finnmark, Northern Norway (Minde 2008, 67-68; Kent 2014, 67-68).
} 
Pietikäinen (2003) has conducted a critical discourse analysis of Saami representations in the Finnish national newspaper Helsingin Sanomat in the period 1985-1993. Critical discourse analysis is also Anna-Lill Ledman's main approach in her doctoral dissertation of 2012 in which she studies how Saami women are represented in the Swedish and Saami press. Lien and Stenhammer (2017) discuss how minorities and indigenous people are represented in Norwegian media from 1900 to WWII. Their time span is relatively long, in that way partly concurrent with my study. Even though the Saami are somewhat overshadowed by other minorities in their study, the comparative perspective is important. The same is the case for Eide and Simonsen (2007) who study how Norwegian newspapers cover minorities (mainly Jews, Romani, Roma, Finns and Saami) in the period 1902-2002. Some of the findings from these studies coincide with mine, but there are also differences.

Virtually, nothing has been written about South Saami representations in the news media. Certainly, Lars Lien has studied how the 'Trøndelag press' cover the first national congress of the Saami in 1917 and his results shed some light on some of the questions I ask. However, in Lien's work, 'Trøndelag press' means the major newspapers of Trøndelag which were all published in Trondheim. ${ }^{7}$ The small-town papers are not included. A few of these papers are included in Skogerbø's survey (2003), among them Trønder-Avisa, Steinkjer, one of the main sources in my study. I will return to some of the studies mentioned above in the concluding parts of my chapter. The objective of my project is to show how the Innherred press covers Saami affairs.

\subsection{Genres and Topics}

Throughout the period as a whole, texts on Saami or Saami-related issues are not prevalent in the papers I have studied. There are about 10 texts per year on average. ${ }^{8}$ However, the number of texts varies to a high degree from one period to the next depending on the general media interest in Saami affairs. The relatively high number of texts in 1917 and 1919 reflects the Saami meetings and Saami political issues in the wake of these meetings. Likewise, around 1980, there is a dramatic increase in the number of texts following the political turmoil connected to the so-called Alta conflict, a turning point for Saami political rights in Norway (see Table 7.1). ${ }^{9}$

As the total number of texts is quite high, I have categorized them according to genre and topic. I have found it beneficial to use the traditional classification into

\footnotetext{
${ }^{7}$ Trøndelag is the central Norwegian region; as of 2018, also the name of the new county replacing the two counties of Nord-Trøndelag and Sør-Trøndelag after they merged.

${ }^{8}$ As a comparison, according to Pietikäinen $(2003,592)$, there were less than six news items per year on average in Helsingin Sanomat 1985-1993. Ijäs (2015) shows much higher figures for Nordlys 1970-2000; not surprisingly, as Nordlys is a major newspaper in Troms county with a relatively large Saami population.

${ }^{9}$ The political struggle against the building of the hydroelectric power plant in the Alta river in Finnmark, Northern Norway (Minde 2008, 67-68; Kent 2014, 67-68).
} 
Table 7.1 Overview of topics (number of texts distributed along periodical timeline)

\begin{tabular}{l|l|l|l|l|l}
\hline Topics/periods & $1880-1900$ & $1901-1921$ & $1922-1945$ & $1946-1966$ & $1967-1990$ \\
\hline $\begin{array}{l}\text { Reindeer herding } \\
\text { (grazing conditions, } \\
\text { predators, land } \\
\text { disputes, etc.) }\end{array}$ & 11 & 37 & 30 & 84 & 141 \\
\hline Saami politics & 0 & 29 & 2 & 22 & 200 \\
\hline $\begin{array}{l}\text { Education and } \\
\text { language }\end{array}$ & 0 & 11 & 7 & 40 & 66 \\
\hline History and Culture & 11 & 42 & 28 & 73 & 148 \\
\hline $\begin{array}{l}\text { Curiosities } \\
\text { Othering/exoticizing }\end{array}$ & 5 & 6 & 1 & 1 & 0 \\
\hline $\begin{array}{l}\text { Criminal cases with } \\
\text { Saami involved as } \\
\text { victims, suspects or } \\
\text { perpetrators }\end{array}$ & 1 & 9 & 3 & 6 & 0 \\
\hline
\end{tabular}

This table gives an indication of how the various texts/topics are distributed throughout the period covered by my study. I have included criminal cases and curiosities as categories, as well as texts significantly characterized by othering and/or exoticizing (cf. similar table in Eide and Simonsen 2007, 30). The high number of texts in the period stretching from 1967 to 1990 is due to the media focus on the Alta conflict, protests against an artillery range in a reindeer grazing area at Fosen, the first Saami parliament election and, not least, the Chernobyl nuclear power plant disaster, which had serious impact on South Saami reindeer herding. The relatively high number in the Criminal cases category 1901-21 is mainly due to the Nordfjell case and the Finn-Paal case (The Nordfjell case: A reindeer owner was convicted for not looking after his own herd according to the law and for shooting reindeer belonging to others. The Finn-Paal case: The Saami Finn-Paal was found dead under suspicious conditions. A Swedish national was charged with murder)

the following three main genre groups (Ottosen 2010, 153-154): News, Opinion and Feature. ${ }^{10}$ Of the 990 texts in my material, $70 \%$ can be classified as News, $10 \%$ as belonging to the Opinion category and around $20 \%$ can be classified as Feature texts. Obviously, there are no clear borders between the genres, so the division is based on my personal judgement in the light of historical conventions. Changing objectivity norms in journalism clearly challenge the division between news and opinion, especially in the oldest newspapers.

Furthermore, I have chosen to categorize the texts into four main topics, with the proportion of the various topics in percentage of the total number of texts:

1. Reindeer herding (grazing conditions, predators, land disputes, etc.): $31 \%$

2. Saami politics: $26 \%$

3. Education and language: $12 \%$

4. History and Culture: $31 \%$.

\footnotetext{
${ }^{10}$ News: from small news items to extensive news stories; Opinion: editorials, commentaries, letters to the editor, etc.; Feature: feature articles, in-depth interviews, etc.
} 
Here again, there are clearly overlapping categories. A news report from a Saami meeting may belong to both the reindeer herding category and the Saami politics category. When in doubt, I have used the historical context and editorial angle as selection criteria. Most of the texts in my material are about matters related to the South Saami area but a few are about Saami affairs in other parts of Fennoscandia.

Reindeer herding is an oft-recurring topic all through the period of my study. Saami politics is an important topic in the decade from 1910 to 1920 and then, it turns up again around 1960 in the wake of the so-called Saami Committee Recommendation $1959^{11}$ (Minde 2003, 77). Throughout the twentieth century, another recurring topic was the struggle to establish a South Saami school. The status of the South Saami language is closely tied to the education topic. This is reflected in several newspaper texts, from the Saami meeting in 1911 to the founding of the South Saami School in Snåsa in 1968 and later. The fourth category, History and Culture, is relatively comprehensive, from popular education articles about South Saami history and culture to sheer curiosities, i.e. news highlighting Saami life as peculiar and strange. Later in the chapter, I will go more deeply into the content, language and meaning of the texts of the four topic areas. Let us first have a look at the ethnonyms used to designate the Saami people throughout history, and how the ethnonym topic is referred to in some of the newspapers as a political issue.

\subsection{Lap, Finn or Saami?}

The way a majority population names a minority reflects power and attitudes. Throughout history, the Saami population has been called Finns, Laps, even Finlaps (Finlapper), often in a derogatory way. The ethnonym question arises early as an important political issue among the Saami. Their own name is Saemie/Sámi. At the Saami meeting in Steinkjer in 1911, there is a 'lively discussion' about the 'Finn name' according to Indtrøndelagen. ${ }^{12}$ The majority voted in favour of changing the subtitle of Waren Sardne from 'Finnernes organ' (The Finns' Voice) to 'Samernes organ' (The Saami's Voice). A few days later, the discussion is referred to in Ranens Tidende ${ }^{13}$ under the headline 'The name is not good enough'. The headline as well as the body text is quite sarcastic, which is not the case for Indtrøndelagen's report, probably reflecting a different editorial policy.

Some years later, in 1929, the folklorist Nils Lagli criticizes the increasing use of the term 'Saami'. In his article 'Lapper eller samer' (Laps or Saami) in Nordlands

\footnotetext{
${ }^{11}$ A Committee, appointed by the Norwegian parliament (Stortinget); the committee's mandate was to report on the so-called "Saami question". The report has been seen as a turning point in Norwegian policies aimed at the Saami (Sametinget 2017; Minde 2003).

${ }^{12}$ Indtrøndelagen 10/3/1911. «Lappemøtet» (The Lap Meeting).

${ }^{13}$ Ranens Tidende 15/3/1911 (Hemnesberget, Nordland county): «Navnet ikke fint nok» (Name not good enough).
} 
Avis ${ }^{14}$ he denounces this usage as a matter of fashion and argues historically and 'scientifically' for the Lap ethnonym. Nils Lagli represents the majority population. It is obvious that the ethnonym question stirs up strong emotions, not only among the Saami. The question appears several times in my material. At the Saami national congress in Trondheim in 1921, a resolution is passed demanding the legal right to the Saami ethnonym. Both Indtrøndelagen and Nord-Trøndelag ${ }^{15}$ print news items about the resolution stating that this has great significance for the Saami. Both papers, as well as Indhereds-Posten, start to use the Saami ethnonym more and more throughout the 1920s (see Fig. 7.1). By the late 1930s, the Lap or Finn ethnonym is used very rarely in my main material.

South Saami as an ethnonym does not seem to be common until the 1950s or 60s. ${ }^{16}$ The first time I find it in my newspaper material is in $1960 .{ }^{17}$ However, a book about the Saami people published in Oslo in 1948 states that the initiative for a Saami national organization came from "the so-called "South-Saami"" (Guttormsen 1948, 70). The wording and the use of quotation marks indicate that the reading public in Norway did not yet commonly know the 'South Saami' term. In any case, the use of the South Saami ethnonym is clearly an important factor when it comes to highlighting the Saami presence in the southern part of Saepmie.

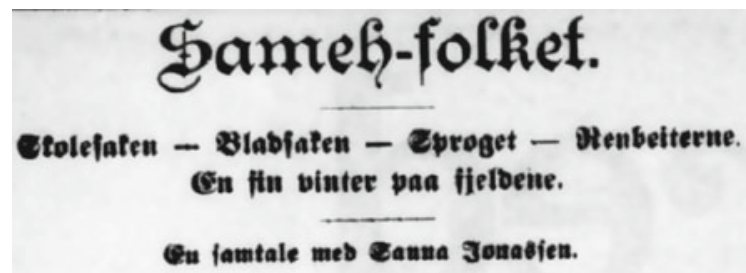

Fig. 7.1 Facsimile from Indherred, 20 March 1919: The heading of the interview with Sanna Jonassen showing an early example of the use of the Saami ethnonym. Note the spelling of 'Samehfolket' (the Saami people). At the time, the word 'same' was not included in Norwegian encyclopedias and dictionaries, and hence no official Norwegian spelling of the term Saami, commonly spelt 'same'. It is interesting that in the depicted headline the word 'Sameh' with the h-ending seems to correspond with the plural form in South Saami: 'saemieh'

\footnotetext{
${ }^{14}$ Nils Lagli: «Lapper eller samer» (Laps or Saami), Nordlands Avis 20/08/1929.

${ }^{15}$ Both papers print news items about the resolution 2/7/1921.

${ }^{16}$ My oldest registration of South Saami used as an ethnonym is in Gustaf von Dübens: Om Lappland och Lapparne [About Lapland and the Laps) where he uses the term 'Syd-lapparne' [the south-Laps] (1873, 442-443).

${ }^{17}$ Trønder-Avisa 19/12/1960.
} 


\subsection{Majority Voices Speaking About or for the Saami}

Only a very few of the texts I have studied can be said to reflect the Saami voice, in the sense that a member of the Saami community is the writer. In quite a few texts, though, we can see that Saami voices are referred to or reported in a relatively objective way. To put it simply, the great bulk of the texts are about Saami affairs in various ways, while some also speak for the Saami. Especially by the 1970s, journalists try to see things from a Saami perspective. In the texts from around 1900 until the 1940s, I have found instances of patronizing attitudes, othering and texts that represent Saami people as exotic, although most texts seem to abide to the current ideals of objectivity. In this and the following sections, I will show how this picture varies throughout the period I have studied, depending on genre, topic and context. The text excerpts used to illustrate my findings have been translated from Norwegian into English. I use the ethnonym Finn, Lap or Sami as used in the source quoted.

\subsubsection{Reindeer Herding}

In 1875, a news story in Indherreds-Posten reflects on the clash of interests between local farmers and the Saami. ${ }^{18}$ What makes the story interesting is that the conflict described in the text is solved through negotiation and goodwill on both sides. We read about a Saami family that has moved with their reindeer herd to a mountain area near Trondheim because of a problem with wolves in the area they left. A local farmer visits the Sami couple to request compensation for damages done to his haystacks by the reindeer. After some disagreement, the Saami wife intervenes with some 'gentle words' and it all ends with an amicable settlement. Although presented as a news story, to a modern reader it appears more as a moral anecdote. The Saami are represented as friendly and hospitable, the underlying message is that conflicts can be solved through dialogue and appropriate compensation.

Is this a typical representation of the relationship between Saami and farmers in the regional press towards the end of the nineteenth century? The expanding farming activities needed more grazing land and there is increasing tension between reindeer herders and farmers by the end of the nineteenth century, not least in the South Saami area (Fjellheim 2012; Salvesen 2017, 43). In 1883, laws were passed in Norway and Sweden to control and restrict reindeer herding in favour of farmers' needs (the socalled Felleslappeloven, the Common Lap Act). The Act introduced state-controlled reindeer grazing districts and corporative responsibility for grazing damage. It made it virtually impossible to reach out-of-court settlements, like the one we can read about in the 1875 text (Jernsletten 1998, 8-10).

As many as one-third of the texts in my material are about reindeer herding in some way or another. Some are about the conflict of interests between farming and

\footnotetext{
${ }^{18}$ Indherreds-Posten 28/5/1875: «Fjeldfinnerne ved Trondhjem» [The mountain Laps near Trondheim]. The text was originally printed in Trondhjems Stiftsavis.
} 
reindeer herders; others are about problems connected to the big carnivores. A typical example is the following short news item from 1917: 'The wolf has recently visited Nikolaus Flaatefjeld's reindeer herd in Spandfjeldet [...] The Laps immediately had to start moving the herd and found 8 killed reindeer.' ${ }^{19}$ In these few words, we are told about the harsh realities the reindeer herders faced. In my material, the carnivore problems dominate the reindeer herding category until the 1970s, then other threats receive more attention for example, hydropower developments and artillery ranges. The clash of interests between agriculture and reindeer husbandry is also represented, although relatively few texts in my material are about local conflicts.

Certainly, some texts indicate a clash of interests for example, this front-page story in 1957: 'The Saami tore down 300 metres of the sheep farmers' fences in Verdal.' In the subheading and body text, however, it appears that it was not obvious that the complaining sheep farmers had a legal right to put up the fences in the first place. At any rate, the Saami are blamed for their actions.

The Saami Committee's report in 1959 recommended a revitalization of Saami language and culture, and a strengthening of traditional Saami trade and livelihood. In a written statement in 1960, The County Farming Association ${ }^{20}$ is critical to some of the views in the report. In Trønder-Avisa their statement is reported across four columns on the editorial page: 'Reindeer herding interests must not prevent good utilization of the mountain pastures. ${ }^{21}$ The news item has a clear farming perspective, not surprising taking into account that $T A$, until 1996, was partly a political organ for Senterpartiet (the agrarian party). The following year a representative of the reindeer herders, Else Jåma, writes a letter to the editor criticizing the Farming Association's proposal to expand the sheep pastures at the expense of the reindeer pastures. ${ }^{22}$ Does her letter indicate that the Saami need to speak out themselves to be heard in the majority media, in this case in a newspaper that traditionally has been seen as a mouthpiece for farming interests?

Still, judging from my material, the press generally represents reindeer herding as something that naturally belongs in the region, and that the main threats are carnivores, hydropower plant construction and other infrastructure issues, not the grazing interests of farmers. In fact, in 1945, a front-page article states that reindeer herding is a commercial interest of great importance to Nord-Trøndelag County. ${ }^{23}$

\subsubsection{Saami Politics}

The backdrop for the political manifestation among the Saami around 1900 was the past 100 years of expanding farming settlements on Saami land, followed by

\footnotetext{
${ }^{19}$ Indtrøndelagen 6/3/1917.

${ }^{20}$ Nord-Trøndelag Landbruksselskap.

${ }^{21}$ Trønder-Avisa 27/6/1960.

${ }^{22}$ Elsa Jåma: «Skal reinbeitene tas til beiter for sau?», Trønder-Avisa 26/10/1961.

${ }^{23}$ Nord-Trøndelag \& Inntrøndelagen 17/1/1945.
} 
laws and regulations restricting reindeer herding and the official assimilation policy that threatened to eradicate Saami culture and language (Lundmark 2008; Fjellheim 2012). The assimilation policy was largely the effect of administrative measures, based on political consensus among majority politicians (Salvesen 2017, 47-48). However, it is possible to trace critical voices in the press. In my material, the first instance is in 1906 in the news item "The Laps complain about their "fellow citizens", (the last phrase is clearly ironic). The text is about Ole Thomassen who has made the journey to Kristiania (Oslo) on behalf of the 'Mountain Laps' to plead the cause of the Saami. The background is the unreasonable compensation legislation in the Reindeer Herding Acts (1883 and 1897) that threatens to impoverish the Saami in dramatic ways. Thomassen's statements are reported: 'We are a homeless people. Still, we are the rightful owners of the land they now, little by little, have taken away from us. ${ }^{24}$ It is the first instance of a Saami voice quoted in my material. A similar statement at the Saami meeting in Namsos 1913 is given a rather patronizing comment by a journalist for Trondhjems Adresseavis (Trondheim) as shown below. Although Indtrondelagen a decade later prints an article by the journalist Ellen Lie of Dagsposten stating that 'the nomadic people' are treated badly in our 'common fatherland' ${ }^{25}$ it is not until the 1960s and later that critical views on the Norwegian state's Saami policy are expressed in plain words by the editor. ${ }^{26}$

A news report on a Saami meeting is printed in 1909. In the text, we can read about all the issues that are raised in the later meetings of the early 1900s: The newspaper issue, the reindeer pasture issue and the school issue. The newspapers in my study have quite extensive reports from the other meetings held in NordTrøndelag County, Steinkjer 1911, Namsos 1913 and Steinkjer 1919. The issues mentioned are also among the focal points of the first national Saami congress in Trondheim in 1917 (Borgen 1997). The longest and most extensive reports are from the meeting in Namsos in 1913. The reports 'Lap and Farmer' 1 and 2 appear in two issues of Indherreds-Posten, copied from Trondhjems Adresseavis. ${ }^{27}$ The newspaper reports are basically unbiased and fair, although there is a tendency to othering in the latter. Part 1 is mainly a rendering of Jon Eliassen's opening speech. In part 2, the discussion following the speech is reported. Here, we can trace a patronizing tone, as in the following remark: 'Be that as it may, whether or not we Norwegians agree with the Laps that they are the aboriginal people of this country. They believe it themselves. Belief is the main thing here. And based on this belief the topic is repeated again and again. ${ }^{, 2}$ Then, Reindeer Inspector Nissen's speech is reported. ${ }^{29}$ As a reader, I am left with the impression that Nissen represents common sense and

\footnotetext{
${ }^{24}$ Indtrøndelagen 19/2/1906.

25 «Dramaet i Snaasen-fjeldene» [The Drama in the Snåsa Mountains] (About the Finn-Paal-case), Indtrøndelagen 11/12/1919.

${ }^{26}$ E.g. in $T A$ 's leading article 10/7/1967 (see Epilogue).

${ }^{27}$ Indhereds-Posten 17/2 and 19/2/1913: «Lap og bumand».

${ }^{28}$ Trondhjems Adresseavis 16/2/1913 and Indhereds-Posten 19/2/1913.

${ }^{29}$ Nils Kristian Nissen (1879-1968) was appointed Reindeer Herding Inspector by the government in 1912.
} 
moderation compared to the somewhat infantile and single-minded commitment of the Saami.

The first national Saami congress in Trondheim in 1917 is to a lesser degree covered in the regional papers of Nord-Trøndelag. There are a few short news items, but no news stories of any length in the papers in my study. However, the national congress is covered quite extensively in the Trondheim papers and the national press (Lien 2011). That the Trondheim congress receives relatively little attention in the papers of the neighbouring county might be due to their regional profile. In addition, of course, comes the fact that the smaller newspapers could not afford special correspondents in the same way as today. The solution was widespread copying from other newspapers, as we see in the case of the above-mentioned 'Lap and Farmer' reports. Nonetheless, this copy practice is also part of the news selection process of the editorial staff and subsequently, the agenda-setting of the newspaper.

\subsubsection{Education and Language}

The wish for a public Saami School in the South Saami area appears for the first time in my material in $1909 .{ }^{30}$ The school question occurs quite frequently in the newspaper texts until 1921, then more sporadically through the 1940s and 50s, until it becomes a more pronounced issue again in the 1960s, until the opening of the South Saami School in Snåsa in 1968. During the 1970s, the Snåsa school is given a fairly high degree of space, e.g. concerning new buildings, South Saami school books and so on.

The first Saami School in Southern Saepmie was in fact established as early as 1910. Haviken Boarding School for Lap Children was founded in Namsos by two Christian organizations, one of which was the so-called Finn (Saami) Mission. ${ }^{31}$ The language of tuition was Norwegian (the children were not supposed to speak their Saami language). The school was run until 1951 when the first state boarding school for South Saami children was opened in Hattfjelldal. According to Indtrøndelagen's report from the 1917 meeting, Sanna and Anton Jonassen criticized the Haviken school for bad hygiene and for not listening to the Saami representatives in the school supervisory committee. ${ }^{32}$ The Jonassen couple was prominent members of the South Saami community actively participating in the early Saami political manifestation. They wanted a state-funded boarding school for Saami children, with as many Saami teachers as possible. Even if the language of tuition had to be Norwegian (at this point there was not yet an official written norm of South Saami), Saami should be maintained (implicitly: as an oral language), as Sanna Jonassen puts it in an interview with Indherred in 1919. I will return to this interview in another context later.

\footnotetext{
${ }^{30}$ In the news report «Lappernes krav» [The Demands of the Laps], Indhereds-Posten 10/12/1909.

${ }^{31}$ Trondhjems Indremisjonsforenig (Home Mission Society) and the Finn Mission (a national evangelism organization dedicated to work for and by the Saami).

32 «Lappeskolen i Haviken», [The Lap school in Haviken], Indtrøndelagen 15/2/1917.
} 
As we can see from the sources, there is a strong wish for a state school. In 1921 , the topic is raised again in the regional papers. Indtrøndelagen gives a brief historic account of the 'School Question' and says that although there is a mission school in Haviken, the Saami in our region want to be treated on equal terms with the Saami in Finnmark (in the far north) and the Norwegians and 'acquire an education in public/state schools and not through gifts of grace' ${ }^{33}$ Later, the same year Nord-Trøndelag launches Snåsa as the location for a public Saami school by $1924 .{ }^{34}$ More specifically, that is what the headline states, in the body text we find a more modified version. The county director of education, Thomassen, says that it is likely that the school will be located in Snåsa because of the soon-to-be-opened new railway line. In retrospect, we can certainly see that this was way too optimistic. It took almost 45 years until the plans were implemented and Aarjel-saemiej skuvle, the South Saami School, was established in 1968. Thomassen emphasizes the need for a Saami School in Trøndelag. As most of the children live in nomadic families, it is difficult to keep them in ordinary schools. He also says that in spite of their way of life, the 'Trønder-Saami' has 'reached an intellectual level that amazes me, and they are strongly distinguished by a joyous urge for enlightenment.' The language question is also mentioned. According to Thomassen, it has to be Norwegian because the 'Trønder-Saami' do not have their own written language, and they do not understand 'Finnmark-Saami' (i.e. North Saami). However, he adds that a couple of the employees should know the 'Trønder-Saami language' in order to establish the best possible contact with the children. ${ }^{35}$

There was a certain disagreement about the language question. At the 1917 congress, Elsa Laula Renberg, one of the initiators of the meeting, spoke about the importance of Saami in school. The other prominent Saami politician and initiator, Daniel Mortenson, pointed out that Saami children should acquire their education in the public folk schools and learn Norwegian; Saami had to be the second priority (Borgen 1997, 64). Not until the establishment of the South Saami School in Snåsa in 1968 is South Saami offered as a school subject. It was the result of the process, mainly in the 1950s and 60s, of developing a written standard for the South Saami language. The key people in this process were Professor Knut Bergsland, teacher Ella Holm Bull and the linguist Gustav Hasselbrink (Sweden). Several of the newspaper texts from the time of the opening of the South Saami school in 1968 and the following decade are about the language topic, in-service courses for South Saami teachers and the development of learning material in South Saami. The coverage is relatively wide and has a positive editorial angle, partly also connected to the development of the South Saami Museum and Cultural Centre at Snåsa, Saemien Sijte, which started as a cultural society in $1964 .^{36}$

\footnotetext{
33 «...faa sin undervisning gjennem statsskoler og ikke gjennem naadegaver», «Skolespørsmålet for lapperne», Indtrøndelagen 25/6/1921.

${ }^{34}$ «Sameskolen for Trøndelag skal bygges på Sem i Snåsa», Nord-Trøndelag, 22/10/1921.

${ }^{35}$ Ibid.

${ }^{36}$ Saemien Sijte's history: https://saemiensijte.no/om-saemien-sijte/historikk/.
} 


\subsubsection{History, Culture-and Curiosities}

Regional (South) Saami culture and history is the topic in quite a few newspaper articles, mostly feature articles, in particular through the 1950s and later. There are a few instances of othering, e.g. in the form of exoticizing, mostly in the first part of the period I have studied, from the late 1800 s to around 1950. This tendency can be spotted in curiosity items copied from other papers, travelogues or fiction; the latter are often serialized. ${ }^{37}$

Some articles refer to the question of Saami presence in the Trøndelag counties in former times. In fact, one controversial topic is the immigration theory launched by the ethnologist and geographer, Professor Yngvar Nielsen (1891). He claimed that the Saami inhabited the areas south of Namdalen as late as the seventeenth and eighteenth centuries. He based his theory on what he found to be an absence of Saami place names, tombs and places of religious worship, e.g. in the Røros area. Later historical and archaeological research has proven him wrong (Bergstøl and Reitan 2008; Norberg and Fossum 2011). In lawsuits brought before the courts as late as the 1990s, lawyers have held Nielsen's immigration theory against the Saami claim that they have used the land since time immemorial and thus have legal right on their side.

We can find echoes of the immigration theory in some of the historical articles in Trønder-Avisa. In 1954, there is an extensive feature article about Røyrvik municipality, an area with a solely Saami presence until the first farmers settled around 1800. The article states that the Saami arrived with their reindeer in the area in the seventeenth century. According to the article, the first people arrived in prehistoric times but the author does not connect these people to the Saami. The article has a clear farming perspective when it says that 'Røyrvik was the last mountain district between Trøndelag and Jämtland to be colonized. ${ }^{38}$ There is no doubt that colonize is used in a positive sense in this context. The general impression is that the $T A$ article is a tribute to the settlers, and 'the colonization that took place at the end of the 18th and beginning of the 19th centuries.' 39

In 1981, the historian and Associate Professor Kjell Haarstad (the University of Trondheim) published a book about Saami migration in southern Norway. Haarstad claims that there are no written sources to prove that Nielsen's immigration theory is wrong. Sverre Fjellheim, Curator of Saemien sijte, writes a critical review of Haarstad's book in $T A{ }^{40}$ Haarstad responds a month later. ${ }^{41}$ In 1984 , there is a critical article on Haarstad's book by a local writer and historian. ${ }^{42}$ Apart from these

\footnotetext{
${ }^{37}$ An example is «Storjord», a family saga from Nordland by Andreas Haukland, Nordenfjeldsk Tidende 16/9/ 1901. In «Storjord» the Saami are characterized by heathenism, ecstasy and savagery (for similar myths about the Saami, see Hermanstrand, 2009, 182-183).

${ }^{38}$ Trønder-Avisa 21/8/1954.

${ }^{39}$ Ibid.

40 "Haarstads vandringer i sørsamisk historie", Trønder-Avisa 28/11/1981.

${ }^{41}$ «Samiske vandringer i Trøndelag», Trønder-Avisa 23/12/1981.

${ }^{42}$ Bjørn Devik: «Apropos til 'Samiske vandringer i Sør-Norge'», 19/9/1984.
} 
articles, there was no debate in TA about Haarstad's book, as far as I have been able to find. In 1985, however, a headline in TA states that the South Saami is not the indigenous people of Trøndelag. The article is referring to a lecture held by Haarstad at the Verdal Historical Society. The essence of the lecture was that the Saami have not been in Trøndelag for more than 300 years. ${ }^{43}$

In fact, already in 1972, there is an article in TA dealing with this apparently 'conventional wisdom' in the wake of Nielsen's theory. The vicar Kåre G. Rogstad, who dedicated much of his time to South Saami history, states that it is a misconception that the Saami came to the Trøndelag Mountains as late as in the 1600s. He bases his view on linguistics, written sources, mythology, place names and archaeological findings. ${ }^{44}$ We can note the echo of the contemporary academic debate on the immigration theory, as Haarstad (1992) and the archaeologists Bergstøl and Reitan (2008) describe it in retrospect, although there are no references to this debate in Rogstad's article.

In the 1960s, there are a few feature articles and stories in $T A$ revealing the Saami presence in former times. One of them, a narrative printed in 1963, even reveals a Saami presence along parts of the Trondheim fjord a couple of 100 years ago, unknown to most members of the majority population today. ${ }^{45}$

On the other hand, there are also articles in the regional newspapers where the Saami absence is striking, as in the following example. In 1936, Nord-Trøndelag og Nordenfjeldsk Tidende presents a double page feature about Namdalen, the northern part of Nord-Trøndelag county, based on a lecture by Adolf Ribsskog, a Steinkjer politician and headmaster. It might be relevant to mention that the lecture was held at a 'Namdal evening' in Bondeungdomslaget, the Agrarian Youth Association. The newspaper feature is about industry, geography and history. The Saami are not mentioned, not even in connection with Namsskogan and Røyrvik which had exclusively Saami settlements until around $1800 .{ }^{46}$ If nothing else, the feature article shows that Saami inclusion was not self-evident, in neither regional nor national historical contexts at the time. ${ }^{47}$ Is it possible that this perspective has been passed on as a mindset until this very day? The ongoing debate about Trøndelags historie [The History of Trøndelag], published in 2005, bears witness to this. The history work has been criticized for obscuring Saami history in key parts of the text, even though the expressed intention was to include regional Saami history (Sem 2017).

The overall picture changes in the post-war period. In the $1960 \mathrm{~s}$ and $70 \mathrm{~s}, T A$ prints articles that can be characterized as genuine enlightenment of the people. Worth mentioning is the series of articles in 1976 by journalist Ola Hjulstad. The

\footnotetext{
43 «Samene ikke urfolk i Trøndealg».

${ }^{44}$ K. G. Rogstad: «Samene til Trøndelagsfjella - truleg misoppfatning at dei kom hit på 1600hundretalet», Trønder-Avisa 21/6/1972.

45 «Pengesekken» (unsigned) [the Money Bag], Trønder-Avisa, 24/12/1963.

${ }^{46}$ «Et og annet om og fra Namdalen», Nord-Trøndelag og Nordenfjelsk Tidende, 18/6/1936.

${ }^{47}$ An illustrative example of the time is the Norwegian National Curriculum for Primary School (the Folk School) 1939. It reflects the contemporary conception of Norway as an ethnically and culturally homogeneous society. There is no mention of Saami people or Saami culture. On the other hand, it says: "Our ancestors belonged to the Germanic tribe."
} 
illustrated full-page articles, 15 in number, about the Saami community in NordTrøndelag, consist of reports and interviews with a pro-Saami perspective. A decade later, we find a number of articles in $T A$ by Åke Jünge with an even more critical view on how the South Saami people have been treated by the majority of society throughout the past century. ${ }^{48}$

\subsection{The Saami Voice}

Although the Saami voice cannot be said to be very significant in the Innherred newspapers in the decades following the 1917 Saami National Congress, there are instances where Saami voices come to the fore in various ways, also in contexts not relating to reindeer husbandry. A person who was not among the well-known Saami profiles of the time, Martin Sivertsen, writes a letter to the editor of Indtrondelagen in 1918. In his letter, he reacts to the abusive language he had been exposed to by 'a well-behaved man' ${ }^{49}$ Sivertsen's letter bears witness to the fact that there indeed was a certain 'popular' antagonism against the Saami that normally was not clearly expressed in the newspapers. Sivertsen cannot understand that an adult male can express himself in such a childish manner and put his honour in doubt by abusing the Saami: 'Even though we belong to the poor nation, we are still a people who have emotions just like you Norwegians'. The letter has a seemingly humble tone but there is a clear ironic touch when he compares those who insult the Saami to 'talking automats'. He concludes by stating that in a way it is good 'that you can see and hear the volcanic elements that appear and how they are turned on and play their music'. 50

In a later letter, Sivertsen refers to the school question discussed at the Saami meeting a few days earlier, 19-21 March 1919 (see Fig. 7.2). ${ }^{51}$ His letter can be interpreted as an example of identity negotiation. 'Saami is our rightful national name,' he writes, 'Laps or Finns are merely borrowed names' [which] 'our brothers, the Norwegians' are tempted to use as nicknames. ${ }^{52}$ The letter concludes with an appeal for inclusion in the Norwegian community: 'We believe that our beloved Mother Norway also has a mother's heart for her stepchildren who live in the mountains so that they also can exist as nomads with their reindeer, which also have a national value for our country. ${ }^{53}$ According to the 1910 Census, Martin Sivertsen is

\footnotetext{
${ }^{48}$ TA 1989. Åke Jünge, Social Geographer, a significant researcher on South Saami history in the Innherred region.

${ }^{49}$ «En talende automat» [A Talking Automat], Indtrøndelagen 22/11/1918.

${ }^{50}$ Ibid.

51 «Statsskole for samerne» [State School for the Saami], Indtrøndelagen 26/3/1919.

${ }^{52}$ Ibid.

${ }^{53}$ Ibid.
} 


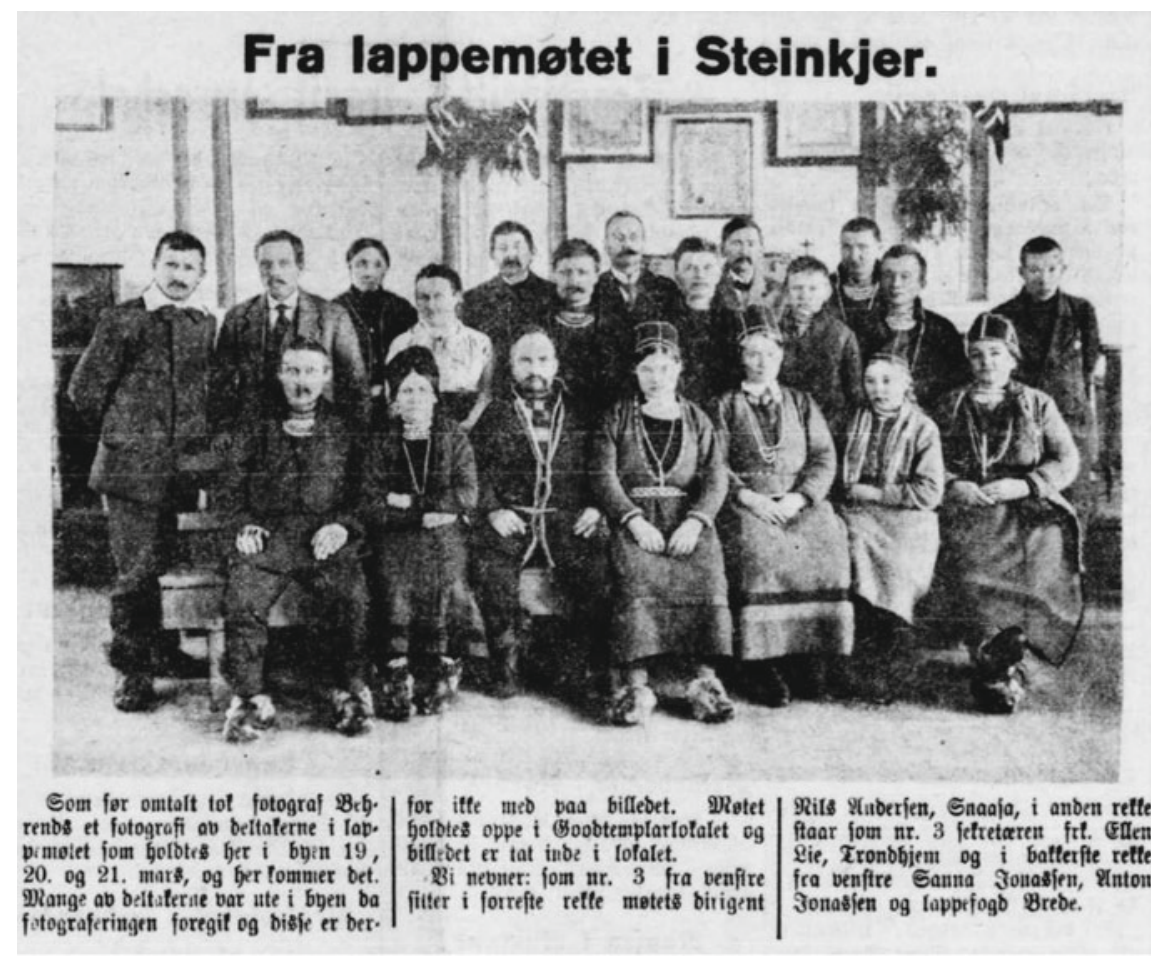

Fig. 7.2 Facsimile from Indherred, 15 April 1919. The photo shows some of the participants in the Saami meeting in Steinkjer 19-21 March. The person standing to the left is probably Martin Sivertsen. In the caption, the following are mentioned (my translation): First row No. 3 from the left: Nils Andersen (the chairman of the meeting). Second row No. 3 from the left: Miss Ellen Lie (Secretary). In the back row, from the left: Sanna Jonassen, Anton Jonassen and Lap Bailiff (lappefogd) Brede

a day worker living not far from Steinkjer town. ${ }^{54}$ His letter is about Saami identity and Saami rights, not primarily about reindeer husbandry or other Saami sustenance.

In 1919, the following headline appears in one of the Steinkjer papers (see Fig. 7.1): 'Sameh-folket' [The Saami People"]. The subheadings indicate the content: 'The School Issue — The Newspaper Issue_-The Language_-The Reindeer Pastures. A Fine Winter in the Mountains. A Talk with Sanna Jonassen'. ${ }^{55}$ The issues listed in the subheading are the important issues in all the Saami meetings also covered by the regional newspapers: Steinkjer 1911, Namsos 1913, Trondheim 1917 and Steinkjer 1919. Sanna Jonassen and her husband Anton Jonassen were both significant voices and initiators of the meetings. The 1919 interview with Sanna Jonassen is an early and unique instance of a Saami voice being referred to in an objective, respectful and

\footnotetext{
541910 Census: https://www.digitalarkivet.no/en/census/person/pf01036874001763.

${ }^{55}$ Indherred 20/3/1919.
} 
empathic way. In that way, it anticipates several interviews and articles in $T A$ some decades later. In 1957, there is a news report about a meeting in Steinkjer Women's Institute with Anna Dærga as the main speaker. The topic is Saami cooking and way of life but questions concerning the school topic and identity are also mentioned. In the article, Anna Dærga is presented as the 'Saami First Lady' of the county. ${ }^{56}$

However, in the 1970s, we see the great change when it comes to giving space to the Saami voice in the newspapers in my study; mainly in Ola Hjulstad's series about the Saami in Nord-Trøndelag County and later in the articles by Åke Jünge. Thus, it might be said that it is by the 1970 s through around 1990 that $T A$ really begins to present Saami culture and history in a tentative Saami perspective. The backdrop is increased attention for the Saami people's situation in the post-war period following a new period of Saami political manifestation. The Reindeer Herders Association of Norway (NRL) is founded in 1948, the Storting (the Norwegian parliament) appoints the Saami Committee in 1956, the same year the Nordic Saami Council is established and in 1968, the Norwegian Saami Association (Norske Samers Riksforbund) is founded. In the 1970s, we see an upsurge of important Saami and environmental issues nationally and locally, like the Alta conflict and the campaign against the artillery range at Fosen.

\subsection{Negotiating Identity}

Saami identity as it is represented in the newspaper texts before the 1970 s is mainly defined through the majority society's perspective, with a few exceptions, among them the interviews and the letters to the editor as mentioned above. What images of the Saami do we see, then, in the newspaper texts throughout the period of my study? A major image until the 1970s is the Saami as reindeer herders living in the outskirts of society. In addition, the Saami appear as highly competent mountain people and hunters. In 1893, a small news item begins like this: 'Two Bears shot by Lap Tomas Eliassen. ${ }^{57}$ The text is typical; the ethnonym is commonly used in relation to the Saami, especially in the oldest texts, more as a vocational designation than purely an ethnonym, parallel to 'farmer' or 'cotter', in line with the conventions of the premodern class society. There are also instances of 'Saami' used as a positive epithet, e.g. 'the well-known Saami [...]'. ${ }^{58}$

The Saami as an able hunter is a recurring topic throughout the period of my study. As hunters of the big predators, the Saami play a positive role, also seen from the point of view of the farming community. Whether you are a sheep farmer or a reindeer herder, the predators are a collective threat. The following headline from

\footnotetext{
56 «Vi foretrekker også en menneskeverdig tilværelse» [We also prefer a decent life], Trønder-Avisa 14/3/1957.

${ }^{57}$ Indherreds-Posten 16/8/1893.

${ }^{58}$ E.g. «Den kjente same Bengt Jåma», Nord-Trøndelag \& Inntrøndelagen, 10/5/1944, «Den kjente samen Peder Jåma» in Nord-Trфndelag \& Inntrøndelagen, 22/3/1945. «Den kjente reinsamen Nils O. Kappfjell», TA 19/1/1967.
} 
1973 illustrates the point: 'Reindeer owners and sheep farmers joined in battle against eagle and lynx'. ${ }^{59}$

In Trøndelag, reindeer herding has been the significant cultural marker of the Saami. Consequently, the image of the Saami living in the outskirts is not surprising. At the same time, this positioning might be seen in metaphorical terms: As an expression of the fact that the Saami were almost made invisible as a result of the Norwegianization process of the first decades of the twentieth century. The problem of the traditional conception of the Saami as it appears in some of the newspaper texts is that it is reductionist and tends to promote stereotyping. That Saami people could have other occupations than reindeer herding hardly appears in the newspaper texts until the 1970s. Then the traditional picture of the hunter and reindeer herder is supplemented with Saami teachers, students, historians, politicians and so on. Alternatively, there may be a combination of the traditional livelihood and other occupations, as we see in an interview with Martha Jåma in 1984. In the text, it appears that she is trained as a teacher, works with Saami handicraft and reindeer herding as well as being the Reindeer Herders Association of Norway's representative in the Sami Rights Commission. ${ }^{60}$ A decade earlier we can read about the reindeer owner Paul Jåma from Verdal studying tourism at the University College of Lillehammer. ${ }^{61}$ In 1975, he and a fellow student present a report about tourism in the reindeer grazing districts. ${ }^{62} \mathrm{An}$ in-depth interview in 1977 with the young Arvid Jåma epitomizes the modern reindeer owner, with business plans, cost estimations and arguments in favour of the nutritional values of reindeer meat. ${ }^{63}$

In several of the texts, there are elements that can be interpreted as negotiations of identity, mainly through descriptions and reflections in texts written by the journalists or other representatives of the majority society. We see this clearly in the 1913 news report 'Lap og bumand' [Lap and Farmer] where the writer definitely shows empathy with the Saami, but they are still 'the others'. In Hjulstad's and Jünge's articles, the Saami is given a voice and the perspective is intentionally Saami. The Saami's own voices are expressed mainly in interviews and letters to the editor. Martin Sivertsen's two texts are particularly interesting. In his texts, we can see that identity is negotiated through both apparent humbleness and a critique of the majority society. In 1977, the question of Saami identity is made explicit in the interview with Arvid Jåma: 'I'm proud of my identity' ${ }^{64}$ The 71-year-old Sofie Stenfjell says in an interview in 1988: 'I'm a Saami, and I'm proud of my family and my people. We have managed to maintain ourselves where most Norwegians would have given up'. ${ }^{65}$

Identity negotiation can be seen in an interview with Lars Børgefjell in 1957. $\mathrm{He}$ accuses the legislators of having a stereotyped conception of the Saami: 'We

\footnotetext{
${ }^{59}$ Trønder-Avisa 15/6/1973: «Reineiere og småfeholdere til felles kamp mot $\varnothing$ rn og gaupe».

${ }^{60}$ Trønder-Avisa 6/7/1984.

${ }^{61}$ Trønder-Avisa 20/10/1973.

${ }^{62}$ Trønder-Avisa 22/3/1975.

${ }^{63}$ Trønder-Avisa 26/2/1977.

${ }^{64}$ Ibid.

${ }^{65}$ Trønder-Avisa 26/3/1988.
} 
Saami seem to be obliged to live in turf huts with an open fire [...] as in days of old' ${ }^{66} \mathrm{He}$ is criticizing the conservation regulations for the Børgefjell Mountains prohibiting the Saami from building cabins. He makes a point out of the fact that the reindeer herders are running a business like everybody else in the country, and that the Saami need to run their business in the best possible way based on the given conditions, which they know better than the lawmakers do. The future of reindeer husbandry and South Saami culture is also the topic in a feature article signed Ola (Hjulstad?) in 1968. He interviews Elsa and Anselm Joma at Høylandet. They miss the good administrative regulations and counselling for reindeer herding that the agricultural and forestry industries have. The couple point to the old Saami councils who negotiated in cases of disagreement. The article gives the impression of a trade at a crossroads between tradition and modernity. Joma claims that the reindeer business is in a critical situation.

Saami handicraft is the main topic of a double page in-depth interview with Anna and Lars Dunfjell in 1971. ${ }^{67}$ The interview acts as an introduction to South Saami history and cultural traditions. The Dunfjells situate themselves geographically, culturally and historically as South Saami, thus contributing to complementing the uniform conception of Saami culture that many members of the majority society had, and possibly still have. A conception influenced by such films as Laila and Same Jakki, as mentioned in the introduction, and later even by the children's television series Ante (1975), all depicting North Saami reindeer herding communities in Finnmark County.

The interview with Martha Jåma in TA in 1984 is also about Saami identity. The Saami Rights Commission's Recommendation to the Storting ${ }^{68}$ and Jåma's role in the Commission is the background of the interview. She makes a point of the fact that the Saami will now be legally defined as a people. Norway has not been leading the way when it comes to minority rights until now, Jåma says, however, if the Storting follows up the recommendation, Saami rights will be established by the Constitution. Earlier only the reindeer herders have been treated as a group in the legal system. 'After all, we in the reindeer trade only form a small part of the Saami people.' At the end of the interview, Jåma speaks about what it is like to be a Saami nowadays compared to earlier times. She thinks that in some fields:

[...] we in the South-Saami area have had it better than the North Saami. We have largely been reindeer herders and consequently had a strong cultural foundation and confidence from home. Moreover, in Nord-Trøndelag there have been few land disputes with farmers.

We have large areas in relation to the population. ${ }^{69}$

Finally, Jåma points out the importance of carrying the Saami culture over to the next generations. The interview shows an authoritative, reflective and politically aware representative of the Saami people. It shows that Saami women take an active part

\footnotetext{
${ }^{66}$ Trønder-Avisa 21/2/1957.

${ }^{67}$ Trønder-Avisa 22/12/1971.

${ }^{68}$ The Norwegian Parliament.

69 «- Først nå blir samene et eget folk etter norsk lov» [Only now the Saami are a people according to Norwegian law], Trønder-Avisa 6/7/1984.
} 
in working life and community life. In that way, there is an interesting link in my material from Sanna Jonassen in 1919 and Martha Jåma in 1984, two interviews that can be seen as antitheses to the tendencies of othering or exoticizing, which are indeed also represented in some of the newspaper texts that I have studied.

\subsection{The Saami as the Other}

In Indherreds-Posten 1891, we find an unsigned Letter to the Editor from Ogndal valley not far from Steinkjer. ${ }^{70}$ The writer claims that the farmers feel almost powerless in relation to the 'Laps, who are lazing about in their huts, letting their reindeer ravage freely with the farmer's property.' An obviously generalizing statement, not on the part of the editor, to be sure, but it reveals an attitude that we can also see traces of in some of the later newspaper texts, though not as explicit as in the letter quoted above. The following example from 1937 is characteristic. A small news item with the heading '27 reindeer on tour to Oslo' tells about Georg Moe from Grong who has planned a tour with some reindeer: 'With Moe there will be five Saami., ${ }^{71}$ They are neither named nor given any address.

In a news item mentioned earlier, we can also see how the Saami are othered through language. In TA 1957: 'The Saami tore down 300 metres of the sheep farmers' fences in Verdal.' Likewise, in a TA news report in 1963 stating that a '[h]erd of reindeer is making trouble on infields in Skogn. ${ }^{72}$ In the first example, we see that the ethnonym is used in the definite plural, which shows the typical negative generalizing frequently used about the 'others'. In the news report from 1963, the farmer affected is named and appears in a photo. The Saami only appear in the text as 'those who own the reindeer.' Thus, the report is clearly biased; the view of the reindeer owners is not given attention. For the farmer, the reindeer is obviously a problem but the way the case is presented turns the Saami as a group into suspects. They are neither named nor given a voice in the matter. In all the examples, the ethnonym is used in an objectifying way where the subtext implies a collectivizing of guilt.

In Nord-Trøndelag 1920, there is a news report from a trial against a Saami defendant. ${ }^{73}$ The report is fairly objective and to the point but in the end, we can read the following: 'This case has the peculiarity of involving only Laps. And they have [as we know] their own way of expressing their thoughts and views. Also in that way the case is of special interest.' Thus, the report is concluded without any further clarification. On July 5 1948, the South Saami community was stricken by a tragic accident. A bus with delegates on their way home from the foundation meeting of

\footnotetext{
${ }^{70}$ Indherreds-Posten 23/12/1891: «Fra Ongdalen [sic]».

${ }^{71}$ Nord Trøndelag og Nordenfjeldsk Tidende 16/1/1937.

${ }^{72}$ Trønder-Avisa 29.4.1963 «Reinsdyrflokk er plagsom på innmark i Skogn».

73 «Saken mot Peder Dærgafjell» [The Case against Peder Dærgafjell], Nord-Trøndelag 6/2/1920.
} 
the NRL ${ }^{74}$ in Troms $\varnothing$ drove off the road in Dunderlandsdalen and 16 passengers lost their lives. The fatal accident made a deep impression on people all over the country and was broadly covered by the media. The day after the accident, Nord-Trøndelag \& Inntrøndelagen writes that the accident is 'doubly tragic because it is very seldom that these people of the mountains use the modern means of communication like cars and buses'. ${ }^{75}$ Here, we see how the stereotypical conception of the Saami as 'children of nature' appears in an otherwise well-intentioned utterance. The othering is expressed both morphologically (these people) and semantically (seldom [using] modern means of communication). Thus, we see until around 1950, a patronizing tone in many texts that are otherwise seemingly pro-Saami; in other words, they are characterized by various degrees of othering.

In places where Saami and farmers have lived together as neighbours, or in other ways have had close contact, objectifying group generalizing should, of course, give way for individual identities. Some interesting evidence of this can be seen in relation to the so-called Finn-Paal case in Snåsa 1919. The Saami Finn-Paal was found dead in the forest, the case was investigated and a Swede was charged with murder. There had apparently been rumours going around about Finn-Paal in the wake of the case. A Letter to the Editor by a 'Mountain Farmer [Fjeldbonde]' in Dagsposten (Trondheim), later copied in Indtrøndelagen, deals with the 'the slander' because 'he knows Paal very well'. The writer describes Paal as an able hunter and an enlightened man with insight into nature and herbal medicine. ${ }^{76}$ A couple of months later the editor of Indtrøndelagen prints an article by Ellen Lie, Dagsposten, about the outrageous deed done to Finn-Paal. The article concludes by stating that FinnPaal belonged to a people that have been treated miserably throughout the times 'in our common fatherland': '[...Those are to be blamed] that have kept the nomadic people in thraldom and ignorance'. ${ }^{77}$ In spite of the tendency of othering, the article is an explicit criticism of the majority society's political approach to the Saami.

An undercurrent in the Norwegian assimilation policy from around 1850 until the 1940s was the view of the Saami as a racially inferior people. However, I have not found that such racial biological attitudes connected to the Saami appear in the editorial articles and news items in the regional papers of my study. On the other hand, I have found a text that can be seen as criticism of the racial biological view of the time. The text 'Samerne [the Saami]' signed Erik E. Erke, Polmak (eastern Finnmark), is printed in Indhereds-Posten in $1919 .{ }^{78}$ The text must be seen in the light of an implied premise for the reindeer herding legislation of 1883 and later, to the effect of the idea that the Saami were a people on the brink of extinction (Eriksen and Niemi 1981, 325-326; Ravna 2007, 221). What is interesting, though, is that the editor of Indhereds-Posten chooses to print Eriksen's text in a prominent place in his paper, in a time when Social Darwinist and racial biological conceptions were

\footnotetext{
${ }^{74}$ Norske Reindriftssamers Landsforbund (Reindeer Herders Association of Norway).

${ }^{75}$ Nord-Trøndelag \& Inntrøndelagen, 6/7/1948.

${ }^{76}$ Indtrøndelagen 16/10/1919.

77 «Dramaet i Snaasen-fjeldene» [The Drama in the Snåsa Mountains], Indtrøndelagen 11/12/1919.

${ }^{78}$ Indhereds-Posten 29/8/1919, originally printed in Østfinmarkens Folkeblad.
} 
still part of the current discourse concerning the Saami and their reindeer herding. It could be interpreted as a critical view on the part of the editor towards these ideas. ${ }^{79}$

In my material, then, there are hardly any examples of explicit racial biological sentiments, as expressed, e.g. in topographical-ethnographical works like Amund Helland's Norges land og folk (1885-1921). In spite of varying degrees of othering and a few cases of exoticizing, the main impression is still that the regional papers in the Innherred region represent the Saami with respect and understanding. My hypothesis is that the Social Darwinist and racial biological ideas were more widespread among anthropologists, natural scientists and other academics than among liberal newspaper editors of the province (Zachariassen 2012, 130).

However, even in seemingly pro-Saami contexts, a generally patronizing attitude is quite common, at least until the 1940s, as we see it in the following excerpt from an interview in 1922 about educating the Saami. In the text, there is even criticism of the prevailing Norwegianization policy 'which has never been as systematic as now', as it says in the introduction. The interviewee is Peter Astrup, Vicar in Lyngen, Northern Norway, who, 'together with a Saami', is planning a folk high school for Saami youth, to compensate for the fact that: 'They [the Saami] have no history, no heroes, no great men to look back on. They have no culture. They only live on loan. ${ }^{80}$

\subsection{Discussion in the Light of Other Studies}

Ijäs (2015) shows how the coverage of Saami matters in Nordlys corresponds to the 'developmental phases' of majority media attention experienced by minority groups in the USA (Native Americans and Blacks) as described by Wilson and Gutiérrez (1985, 133-142). After the so-called 'Exclusionary Phase', the Alta conflict resulted in increased press coverage comparable to the 'Threatening-Issue Phase' and subsequent 'Confrontation Phase', according to Ijäs. The press coverage of the Saami meetings in my material follows to a certain degree the same pattern. After the Saami meetings in the period 1917-1921, there is increased media attention, followed by a period of relatively few texts annually until the 1960s. Although the American and Norwegian experiences are different in many ways, we see some of the same structures at work concerning the attention the majority media give to indigenous minority people, in Norway, most significantly in the wake of the protest movement sparked by the Alta conflict around 1980. After the 'Confrontation Phase', we see a restoration of social order, what Wilson and Gutiérrez describe as the 'Stereotypical Selection Phase'. This implies, in their view, a restoration of social

\footnotetext{
${ }^{79}$ The editor of Indhereds-Posten at the time was O.L. Elnan (1887-1957) who was an active member of the Det Radikale Folkeparti (Arbeiderdemokratene) [The Radical People's Party (the Labour Democrats)], a non-socialist, liberal, Labour Party.

${ }^{80}$ «Også et misjonsarbeide. [Also a Mission Task], Nord Trøndelag og Nordenfjeldsk Tidende, $12 / 12 / 1922$.
} 
order and transformation 'into a post-conflict period' whereby the majority public is reassured that the minorities are still in 'their place' and not a threat to society (1985, 138-139). There are considerably fewer texts about Saami affairs in TA after 1980, just as in Nordlys (Ijäs 2015, 91). However, I would not generally say that the texts in $T A$ 'reinforce existing stereotypes' by way of presenting 'ethnics' as 'people who either have problems or cause problems for society', as Wilson and Gutiérrez describe typical traits of the Stereotypical Selection Phase (Wilson and Gutiérrez 1985, 139). As far as I can see, TA presents Saami affairs in a relatively balanced way, focusing on problems as well as positive news, in line with the editorial angle on news in general.

According to Pietikäinen (2003), the Saami are almost invisible in the news coverage of Helsingin Sanomat 1985-1993. The news coverage of the Saami is coloured by their role as victims of majority politics. Their own voice is hardly heard. The Saami are generally represented as a homogenous group connected to nature and traditional trades, whereas the members of the majority population actively represent the governmental system. Her study is not quite comparable to mine, neither in timespan nor context (regional newspapers vs. national newspaper, etc.). While some of the same tendencies are also found in the regional newspapers of my study, especially in the first half of the twentieth century, here we see to a greater extent than in Pietikäinen's study that the Saami are represented as active citizens who are heard by politicians, editors and other authorities, especially from the 1970s.

Pietikäinen (2003) refers to international research on media representation of ethnic minorities where the typical picture is 'a context of problems, crime and disturbance' (p. 587). She points out, however, that this is not adequate for the representation of the Saami; it is rather the case for the newer minorities (in her study: Rom, Russians and Somalians). This also seems to coincide with the findings of my study. There are disputes on grazing rights and reductions of pastures due to watercourse regulations and so on, but the Saami affairs are not more connected to conflict than other groups when it comes to the overall mass media focus on conflict in general. This might be due to what Skogerb $\varnothing(2003,367)$ mentions as a characteristic of local journalism, namely a downscaling of conflict and local identity building. Concerning the latter, throughout the post-war period, $T A$ presents the Saami people and Saami culture as a natural part of the regional identity.

Lien and Stenhamar (2017) state in the conclusion of their article on the Norwegian press' representation of minorities 1900-1940 that 'Jews, Saami, Romani and Rom [were] connected to crime and [National] disloyalty' (ibid., 59). That the Saami were particularly connected to crime does not agree with my study. When it comes to criminal cases, I have only found three texts about cases in the South Saami area in which Saami people are charged and prosecuted. In other cases, Saami people are the victims of criminal acts. ${ }^{81}$ The press coverage is not sensational, but rather subdued. Locally, only in the coverage of the Nordfjell case have I found subtexts implying

\footnotetext{
${ }^{81}$ In two cases, Saami girls are the victims of rape by a "tramp" (1913) and a Russian hotel owner in Trondheim (1920). In the "Finn-Paal case" (1919), a Swedish national was convicted of contributing to the death of Finn-Paal.
} 
a possible connection between Saami and criminal. Such a connection can also be traced in this national news item in 1955 when TA prints the following headline: 'Three Saami confess to the murder of a mentally ill escapee on Finnmarksvidda' ${ }^{82}$ The use of the ethnonym reflects othering and negative group identification. The explanation might be that the Saami in question are not local. The news source is the Norwegian news agency NTB (cf. the characteristics of local journalism according to Skogerbø 2003, cited above).

That the Saami people are associated with nature and reindeer herding ('these people of the mountains') is prevalent in the newspaper coverage until the 1960s, then this traditionally essentialist view is replaced by a more open and flexible conception of Saami identity. That the Saami are represented as a people in their own right, different from the majority population, is not negative in itself, of course. On the other hand, this might be the case in contexts where ethnonym or group designation appears as othering; i.e. the use of a certain set of ethnic markers functioning as stereotyping, and consequently reductionist. Ledman $(2012,44)$ discusses stereotypes and ethnic markers in the light of the cultural theorist Stuart Hall and the social anthropologist Thomas Hylland Eriksen. ${ }^{83}$ Hylland Eriksen's point is that stereotypes in a certain sense may, in fact, mean making visible, and thus paradoxically having a positive function. In our context that would imply, to put it bluntly, that it is better that the Saami are represented as 'the other' than not being seen or mentioned at all, as in the feature article about Namdalen in 1936. On the other hand, as Ledman expresses in accordance with Hall's view, stereotyping is exclusionary and reduces the individual to his/her 'natural properties' instead of being a socially created and changeable subject. The representation of the Saami in Trфnder-Avisa and its predecessors varies between othering and inclusion. In some cases, the othering is subtle, baked into the choice of words and syntax, in other cases obvious. To decide whether it is the one or the other is a question of interpretation based on context and perspective.

\subsection{Epilogue}

When reading a relatively large amount of disparate texts distributed along a time axis, as with the newspaper texts of my study, the texts will easily appear as episodes of a narrative with a plot. The historian Hayden White ([1973] 2014) describes and discusses this phenomenon, which he calls emplotment. Obviously, this might turn out to be a possible simplism, an interpretative pitfall, in a project like my own. Still, taking this reservation into consideration and in spite of the objection, if you read the newspaper texts as scenes of a novel about the South Saami in Innherred, what would the plot be?

\footnotetext{
${ }^{82}$ Trønder-Avisa 24/11/1955.

${ }^{83}$ Ledman refers to Thomas Hylland Eriksen, Etnicitet och nationalism. Nya Doxa, Nora 1998 and Stuart Hall, "The Work of Representation" and "The Spectacle of the Other" in Stuart Hall (ed.), Representation. Cultural representations and signifying practices. London, Thousand Oaks, New Delhi, Singapore 2011 [1997].
} 
It starts with a harmonious rendering of a meeting between a farmer and a Saami couple in 1875, then a degree of attention by the press in the wake of the early Saami meetings, until it all ends with the Saami becoming gradually more visible and even given a voice in Trфnder-Avisa a 100 years later. From seeming harmony via near obscurity to visibility. The circle completed, as it were. It is probably more accurate to say that the media attention and story angle develop according to societal attitudes and governmental politics concerning the Saami. Perhaps a new consciousness about the Saami is heralded in 1967 when the TA editor criticizes the Norwegian state's policy towards the Saami and the public's lack of engagement. ${ }^{84}$ He writes that all Norwegians have been aware of the criticism of the Saami for decades but nobody has protested. He points out the great concern among Norwegians for the Blacks in the USA but that we need to put our own house in order before criticizing others. In the period 1977-1980, there are several pro-Saami editorials in Trønder-Avisa, including some opposing the regulation of the Alta-Kautokeino river system.

My conclusion is that the representation of South Saami culture, language and community life in Trфnder-Avisa during the 1970s and 1980s has come a considerable way towards Saami inclusion and a Saami perspective. Whether today's editorial staff is closer to that goal is an interesting question, but beyond the frame of this study.

Wilson and Gutiérrez $(1985,139)$ talk about the goal of 'the integrated Coverage Phase'; at the time of their writing, this was 'still largely a vision' in the US. Indigenizing the majority mind is still somewhere in the future, also in Norway. However, in 2017, there was considerable attention, among politicians and in the media, around the centennial of the first Saami National Congress in Trondheim in 1917-and in 2017, the Saami were again present at the Levanger winter market.

\section{Bibliography}

Allingham, William. 1807. Diary from his stay in Norway. Handwritten manuscript. Katalognr Gunnerus XA, Qv, 1023, The Gunnerus Library, Norwegian University of Science and Technology, NTNU, Trondheim.

Bergstøl, Jostein, and Gaute Reitan. 2008. Samer på Dovrefjell i vikingtiden - et bidrag til debatten omkring samenes sørgrense i forhistorisk tid. [Saami Presence in Dovrefjell in the Viking Age]. Historisk tidsskrift 01/2008 (Volume 87), 9-27.

Borgen, Peder. 1997. Samenes første landsmфte 6.-9. februar 1917: Grunnlaget for samefolkets dag 6. februar: Historisk oversikt - Dokumentasjon - Kommentar. [The first national Saami Convention 6-9 February 1917: The Foundation of The National Day of the Saami 6th February: Historical Survey_Documentation_Comments]. Trondheim: Tapir Forlag.

Christensen, Cato. 2012. «Overtroen er stor blant viddenes folk». Om religion og koloniale relasjoner i samisk filmhistorie. ["Superstition is High among the People of the Plains". On Religion and Colonial Relations in Saami Film History]. Tidsskrift for kulturforskning. Vol. 11.

Düben, Gustaf von. 1873. Om Lappland och Lapparne, företrädesvis de svenske. Ethnografiska Studier. [About Lapland and the Laps, mainly the Swedish]. Stockholm: P. A. Norstedts Söners Förlag.

${ }^{84}$ Trønder-Avisa 10/7/1967. 
Eide, Elisabeth, and Anne Hege Simonsen. 2007. Mistenkelige utlendinger. Minoriteter i norsk presse gjennom hundre år. [Suspicious foreigners. Minorities in Norwegian Press over a century]. Kristiansand: Høyskoleforlaget.

Eliassen, Emil M., Toralf Granaune, Anne Grønli, Tore Sæther, Arild E. Pettersen, and Sveinung Havik. 2007. Levangermartnan gjennom 1000 år [Levanger Market through a 1000 Years]. Accessed May 4, 2018. http://www.levanger.kommune.no/PageFiles/379933/levangermartnan gjennom_1000_ar.pdf.

Eriksen, Knut Einar, and Einar Niemi. 1981. Den finske fare: Sikkerhetsproblemer og minoritetspolitikk i nord 1860-1940. The Finnish Danger: Security Problems and Minority Policy in the North 1860-1940. Oslo, Bergen, Tromsø: Universitetsforlaget.

Fjellheim, Sverre. 2012. Gåebrien sijte: en sameby i Rørostraktene. [Gåebrien sijte: A Saami Village in the Røros Area]. Røros: Sverre Fjellheim.

Guttormsen, Anders (ed.). 1948. I lys av фstenstjernen. Trekk fra samenes folkeliv og kultur. [In the Light of the Eastern Star. Aspects of the Saamis' Daily Life and Culture]. Oslo: Norsk Luthersk Forlag.

Haarstad, Kjell. 1981. Samiske vandringer i Sør-Norge. [Saami migration in the south of Norway]. Trondheim: Tapir. Universitetet i Trondheim.

Haarstad, Kjell. 1992. Sørsamisk historie. Ekspansjon og konflikter i Rørostraktene 1630-1900. [South Saami history. Expansion and conflicts in the Røros area 1630-1900]. Trondheim: Tapir Forlag.

Hammond, Hans. 1787. Den Nordiske Missions-historie i Nordlandene, Finmarken og Trundhiems Amt til Lappers og Finners Omvendelse, fra forste Begyndelse indtil hen udi Aaret 1727, da Lappernes og Finnernes Apostel Thomas von Westen døde, tilligemed denne udødelige Mands Levnetsbeskrivelse: samt Anhang om de første Missionariis og andre Missionens Medhielpere. København: Gyldendal, 455.

Helland, Amund. 1899. Norges land og folk. [Land and People of Norway] Vol XIX Troms $\phi$ Amt [Troms $\varnothing$ County]. Kristiania: H. Aschehoug \& Co.s Forlag.

Hermanstrand, Håkon. 2009. Røyrvik: Samene i Østre Namdal [The Saami in Eastern Namdal]. Røyrvik: Røyrvik kommune.

Ijäs, Arne Johansen. 2012. Samer i to norske nyhetsmedier. [Saami in two Norwegian News Media]. Guovdageaidnu: Dieðut 1/2012. Sámi allaskuvla.

Ijäs, Arne Johansen. 2015. Fra usynlig til synlig: Omtaler av samer i avisa Nordlys 1970-2000. [From Invisible to Visible: Reports on Saami in the Newspaper Nordlys 1970-200]. Pressehistorisk Tidsskrift 24/2015, 83-91.

Jernsletten, Regnor. 1998. Samebevegelsen i Norge. Idé og strategi 1900-1940. [The Saami Movement in Norway. Idea and Strategy 1900-1940]. Tromsø: Senter for samiske studier, Universitetet i Tromsø.

Jordheim, Helge. 2015. The nature of civilization: The semantics of civilization and civility in Scandinavia. In Civilizing emotions: Concepts in nineteenth century Asia and Europe, ed. Margrit Pernau et al. Oxford: Oxford University Press.

Kent, Neil. 2014. The Sámi peoples of the north. London: Hurst \& Company.

Kolberg, Asbjørn. 2018. "Samer er vort rette nationale navn" - hundre års sørsamiske representasjoner I nordtrønderske aviser ["Saami is our rightful national name"-a hundred years of South Saami Representations in Newspapers in Nord-Trøndelag County]. Heimen 1-2018. Oslo: Universitetsforlaget, 31-49.

Krippendorff, Klaus. 2004. Content analysis: An introduction to its methodology, 2nd ed. Thousand Oaks, London, New Delhi: Sage.

Ledman, Anna-Lill. 2012. Att representera och representeras. Samiska kvinnor i svensk och samisk press 1966-2006 [To represent and be represented. Sami women in Swedish and Sami press, 1966-2006]. Umeå: Institutionen för idé- och samhällsstudier, Umeå universitet. 
Lien, Lars. 2011. 6. februar - Dekningen av samenes første landsmøte i trøndelagspressen, 1916-1917. [6th of February-The Coverage of the First Saami National Congress in the Trøndelag press, 1916-1917] In Utenfor det etablerte. Aspekter ved Einhart Lorenz' forskning, ed. Øivind Kopperud et al. Oslo: HL-senteret.

Lien, Lars and Madeleine Zetterlund Stenhammer. 2017: «De fremmede i pressen". Omtale av nasjonale minoriteter og urfolk i media fra 1900 til andre verdenskrig. ["The others in the press". Representations of national minorities and indigenous people in the media from 1900 to the second world war]. In Nasjonale minoriteter og urfolk, ed. Nik. Branddal et al. Oslo: Cappelen Damm.

Lundmark, Lennart. 2008. Stulet land: svensk makt på samisk mark [Stolen land: Swedish power on Saami ground]. Stockholm: Ordfront Förlag.

Minde, Henry. 2003. The challenge of indigenism: The struggle for Sami land rights and selfgovernment in Norway 1960-1990. In Indigenous peoples: Resource management and global rights, ed. Svein Jentoft, Henry Minde, and Ragnar Nilsen. Eburon: Delft.

Minde, Henry. 2008. The Destination and the Journey. Indigenous Peoples and the United Nations from the 1960s through 1985. In Indigenous peoples: Self-determination, knowledge, indigeneity, ed. Henry Minde. Delft: Eburon.

Nielsen, Yngvar. 1883. Reisehaandbog over Norge. [Travellers' Handbook of Norway]. Kristiania: Alb. Cammermeyer, 418.

Nielsen, Yngvar. 1891. Lappernes fremrykning mot syd i Trondhjems Stift og Hedmarkens Amt. [The Laps' Advance towards the South in Trondhjem's Diocese and Hedemarken's County]. Kristiania: Det Norske Geografiske Selskabs Aarbog I 1889-90, 18-52.

Nielsen, Yngvar. 1900. Lapperne [The Laps]. In Norge i det nittende aarhundre, ed. Nordahl Rolfsen. Andet bind. Kristiania: Alb. Cammermeyers Forlag.

Nielsen, Yngvar. 1909. Erindringer fra et halvt Aarhundredes Vandreliv. [Memories of half a century's Rambler's life]. Kristiana, Copenhagen: Gyldendalske Boghandel Nordisk Forlag.

Nissen, Per. 1914. Fadrelandet: En Norges-beskrivelse for landsmand hjemme og ute. [The fatherland: A description of Norway for countrymen at home and abroad]. Kristiania: H. Aschehoug \& Co's Forlag.

Norberg, Erik, and Birgitta Fossum. 2011. Traditional knowledge and cultural landscape. Diedut 1/2011. Guovdageaidnu/Kautokeino: Sámi allaskuvla/ Sámi University College.

Normalplan for byfolkeskolen. [1939] 1948. Kirke- og undervisningsdepartementet. Oslo: Aschehoug. Retrieved from http://www.nb.no/nbsok/nb/9062bbc35c8048a477e9ff413a9ec486? index $=2 \# 0$.

Ottosen, Rune, ed. 2010. Norsk presses historie 1-4 (1660-2010), [The history of the Norwegian Press 1-4 (1660-2010)]. Vol. 2: Parti, presse og publikum 1880-1945, Oslo: Universitetsforlaget, $153-173$.

Pietikäinen, Sari. 2003. «Indigenous Identity in Print: Representations of the Sami in News Discourse». Discourse \& Society 14 (5): 581-609. London: Sage.

Ravna, Øyvind. 2007. Reindriftssamenes bruksretter og jordskifterettens saklige kompetanse. Tidsskrift for Rettsvitenskap, Vol. 120, 1-2/2007, 220-251.

Salvesen, Helge. 2017. Saemieh aelkieh sijjen mïelem jietedh - Samane tek til orde [The Saami speak out]. In Vaerien Almetjh - Fjell-Folk 2017, Årbok for Rørosmuseet $n r$. 42, ed. R. Borgos, J. Fjellheim, and T. Rygg. Røros: MiST Rørosmuseet, 41-56.

Sametinget [Saami Parliament]. 2017. Historikk. Fornorskningen [History. Norwegianization]. Accessed March 5, 2018: https://www.sametinget.no/Om-Sametinget/Bakgrunn/Historikk\#.

Sem, Leiv. 2017. Om framstillinga av sørsamar i Trøndelags historie [About the Presentation of South Saami in the History of Trøndelag]. Heimen 2-2017. Oslo: Universitetsforlaget, 130-144.

Skogerb $\varnothing$, Eli. 2003. Mediene og det samiske samfunnet: Stereotyper og identitetskonflikter [Media and the Saami community: Stereotypes and identity conflicts]. In Samer, makt og demokrati: sametinget og den nye samiske offentligheten, ed. Bjørn Bjerkli and Per Selle. Oslo: Gyldendal, kap. 14. 
Trapness, Albert Kjørboe. 2002. Min barndoms by [The Town of My Childhood] (excerpt from Farende Svend. Fra haanverkslivet i gamle dage, 1922). In Albert Kjørboe, Trapness: Levanger - før jernbanens tid, Levanger: Levanger historielag.

White, Hayden. [1973] 2014. Metahistory: The historical imagination in nineteenth-century Europe, Fortieth-Anniversary Edition. Baltimore: Johns Hopkins University Press.

Wilson, Clint C., and Félix Gutiérrez. 1985. Minorities and media. London: Sage.

Zachariassen, Ketil. 2012. Samiske nasjonale strategar. Samepolitikk og nasjonsbygging 1900-1940 [Saami national strategies. Saami politics and nation building]. Karasjok: ČálliidLágádus.

Open Access This chapter is licensed under the terms of the Creative Commons Attribution 4.0 International License (http://creativecommons.org/licenses/by/4.0/), which permits use, sharing, adaptation, distribution and reproduction in any medium or format, as long as you give appropriate credit to the original author(s) and the source, provide a link to the Creative Commons licence and indicate if changes were made.

The images or other third party material in this chapter are included in the chapter's Creative Commons licence, unless indicated otherwise in a credit line to the material. If material is not included in the chapter's Creative Commons licence and your intended use is not permitted by statutory regulation or exceeds the permitted use, you will need to obtain permission directly from the copyright holder.

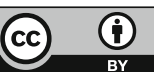

